\title{
POTENSI DAN STRATEGI PENGEMBANGAN PERTANIAN PADA KELOMPOK TANI SUMBER KLOPO I
}

\author{
POTENTIALS AND AGRICULTURAL DEVELOPMENT STRATEGIC in \\ FARMERS of SUMBER KLOPO I \\ Nurul Fathiyah Fauzi \\ Program Studi Agribisnis, Fakultas Pertanian, Universitas Muhammadiyah Jember \\ e-mail: nurul.fauzi@unmuhjember.ac.id
}

\begin{abstract}
ABSTRAK
Pengembangan sektor pertanian di pedesaan menghadapi berbagai tantangan. Beberapa faktor teknis dan nonteknis juga ditengarai menjadi kendala dalam pembangunan pertanian di masa yang akan datang. Desa Sumber Klopo yang terletak di Kecamatan Bangsalsari Kabupaten Jember merupakan salah satu desa yang memiliki potensi pertanian yang melimpah. Desa ini berada pada daerah dataran tinggi di wilayah Kecamatan Bangsalsari. Potensi yang ada diantaranya ketersediaan lahan pertanian, adanya sector perkebunan, hortikultura dan tanaman pangan, ketersediaan SDM pertanian, dan adanya kegiatan kelompok tani yang aktif. Potensi yang dimiliki ini memiliki berbagai kendala dan masih belum dimanfaatkan secara optimal agar mampu meningkatkan pendapatan petani dan keluarga. Tujuan penelitian untuk mengetahui dan menggali lebih dalam mengenai potensi dibidang pertanian dan merancang strategi pengembangan terhadap potensi pertanian yang ada pada Kelompok Tani Sumber Klopo I. Metode penelitian dengan deskriptif analitik yang dilakukan secara purposive method pada Kelompok Tani Sumber Klopo I. Sampling diambil 3 orang expert. Analisis data dengan deskriptif dan Analisis Medan Kekuatan (Force Field Analysis/FFA). Hasil menunjukkan 1) potensi pertanian Kelompok Tani Sumber Klopo I yakni: a) SDM aktif dalam kegiatan kelompok tani dan adopsi inovasi, b) penghasil pangan-palawija-perkebunan dengan komoditas pangan an perkebunan utama yakni padi dan kopi, c) lahan pertanian yang subur, d) memiliki 2 unit kios sarana produksi pertanian, dan e) resiko gangguan OPT yang kecil. 2) Strategi pengembangan pertanian yang dapat diterapkan yakni: a) Pemberdayaan kelembagaan serta organisasi petani, b) Revitalisasi sistem inovasi teknologi dengan mempertimbangkan aspek penelitian, pengembangan dan jaringan inovasi interaktif, c) Pengembangan akses jaringan komunikasi.
\end{abstract}

Kata kunci : Analisis Medan Kekuatan, potensi pertanian, strategi pengembangan pertanian

\begin{abstract}
The development of the agricultural sector in the countryside faces various challenges. Several technical and non-technical factors are also suspected to be obstacles to agricultural development in the future. Sumber Klopo Village located in Bangsalsari District, Jember Regency is one of the villages that has abundant agricultural potential. This village is located in a highland area in Bangsalsari District. Potentials include the availability of agricultural land, the existence of plantation, horticulture and food crops, availability of agricultural human resources, and the existence of active farmer group activities. This potential has various constraints and is still not used optimally to be able to increase the income of farmers and families. The research objective was to find out and explore more about the potential in agriculture and design development strategies for agricultural potential in the Sumber Klopo Farmer Group I. Analytical descriptive research method was carried out by purposive method in the Sumber Klopo Farmer Group I. Sampling was taken by 3 experts. Data analysis with descriptive and Force Field Analysis (FFA). The results show 1) the agricultural potential of the Sumber Klopo I Farmers Group, namely: a) active human resources in farmer group activities and adoption of innovation, b) food-crops-planters with food commodities and main plantations namely rice and coffee, c) fertile agricultural land, d) has 2 kiosk units for agricultural production, and e) the risk of small pest disturbances. 2) Agricultural development strategies that can be implemented are: a) Institutional empowerment and farmer organizations, $b$ ) Revitalization of technological innovation systems by considering aspects of research, development and interactive innovation networks, $c$ ) Development of communication network access.
\end{abstract}

Key words: Force Field Analysis (FFA), agricultural potentials, agriculture development strategy 


\section{PENDAHULUAN}

Pengembangan sektor pertanian di pedesaan menghadapi berbagai tantangan dengan makin terbatasnya kepemilikan lahan oleh petani. Jumlah petani gurem meningkat dari 10,80 juta pada tahun 1993 menjadi 13,66 juta pada tahun 2003, dan diperkirakan lebih dari 15 juta petani pada tahun 2010 (BPS 1993; 2003). Beberapa faktor teknis dan nonteknis juuga ditengarai menjadi kendala dalam pembangunan pertanian di masa yang akan datang, seperti menurunnya kapasitas dan kualitas infrastruktur, konversi lahan, degradasi lahan dan air, perubahan iklim, kerusakan lingkungan, kesenjangan hasil antara di tingkat penelitian dan di petani, kurang menariknya kegiatan pertanian bagi generasi muda, serta persaingan penggunaan lahan antara sektor pertanian dan nonpertanian (infrastruktur, industri, perkotaan/pemukiman).

Desa Sumber Klopo yang terletak di Kecamatan Bangsalsari Kabupaten Jember merupakan salah satu desa yang memiliki potensi pertanian yang melimpah. Desa ini berada pada daerah dataran tinggi di wilayah Kecamatan Bangsalsari. Potensi yang ada diantaranya ketersediaan lahan pertanian, adanya sector perkebunan, hortikultura dan pertanian tanaman pangan, ketersediaan SDM pertanian, dan adanya kegiatan kelompok tani yang aktif. Potensi yang dimiliki ini memiliki berbagai kendala dan masih belum dimanfaatkan secara optimal agar mampu meningkatkan pendapatan petani dan keluarga.

Berbagai potensi dan tantangan dalam pengembangan sektor pertanian ini diharapkan mampu untuk dikelola dan diatasi dengan baik. Peran serta petani, pemerintah, perguruan tinggi dengan tridharma-nya, serta masyarakat umum sangat diperlukan dalam mendukung peningkatan potensi dan pengembangan sector pertanian. Oleh karena itu, dalam upaya pengembangan ini diperlukan beberapa alternatif startegi

Tujuan yang ingin dicapai dari penelitian ini yakni: 1) mengetahui dan menggali lebih dalam lagi mengenai potensi dibidang pertanian yang ada pada Kelompok Tani Sumber Klopo I. 2) merancang strategi pengembangan terhadap potensi pertanian yang ada pada Kelompok Tani Sumber Klopo I.

\section{METODE PENELITIAN}

Penentuan daerah penelitian dilakukan secara sengaja (Purposive Method) yakni di Kabupaten Jember, tepatnya dilakukan pada Kelompok Tani Sumber Klopo I Desa Sumber Klopo Kecamatan Bangsalsari Kabupaten Jember. 
Dasar pertimbangan penentuan daerah penelitian yakni daerah tersebut memiliki potensi pertanian yang beragam dari tanaman pangan, buah, dan perkebunan kopi hanya saja potensi tersebut belum dimanfaatkan secara optimal oleh kelompok tani dan keluarga. Metode penelitian yang akan dilakukan dalam penelitian ini yakni menggunakan metode deskriptif dan analitik dengan data sekunder dan primer. Sampel yang dibutuhkan hanya sampel expert (sampel yang dianggap ahli dan menegtahui tentang potensi daerah penelitian). Jumlah sampel expert yang akan diambil yakni 3 orang terdiri dari ketua kelompok, penyuluh pertanian yang bertugas di wilayah daerah penelitian, serta satu orang anggota kelompok tani.

Metode analisis data yang digunakan untuk menjawab permasalahan pertama yakni dengan menggunakan metode deskriptif. Menurut Soetriono dan Rita Hanafi (2007), penelitian deskriptif bertujuan membuat pencanderaan/ lukisan/deskripsi mengenai fakta-fakta dan sifat-sifat suatu populasi atau daerah tertentu secara sistematis, faktual, dan teliti. Variabel-variabel yang diteliti terbatas atau tertentu saja, tetapi dilakukan secara meluas pada suatu populasi atau daerah itu. Biasanya penelitian semacam ini disebut survai (jadi berbeda dengan studi kasus, dimana fakta-fakta dan sifat-sifatnya dipelajari selengkapnya secara mendalam tetapi hanya pada satu unit tertentu saja).

Metode analisis untuk menjawab permasalahan kedua menggunakan Analisis FFA atau Analisis Medan Kekuatan. Adapun tahapan-tahapan dalam melakukan analisis FFA adalah sebagai berikut (Sianipar dan Entang, 2003):

1. Mengidentifikasi masalah berdasarkan isyu strategis. Isyu strategis ini dapat meliputi aspek sosial, aspek ekonomi, aspek input, aspek teknis, aspek pasar, dan aspek output dari sistem panen dengan jual sendiri dan sistem tebasan

2. Menganalisis masalah dengan mengidentifikasi berbagai kekuatan pendorong (driving force) dan kekutan penghambat (restraining force).

3. Memberikan penilaian skala prioritas terhadap setiap faktor pendorong dan penghambat.

Penilaian setiap faktor yang teridentifikasi sangat menentukan faktor keberhasilan tujuan. Penentuan nilai dilakukan dengan menganalisis faktor pendorong dan penghambat dari adanya sistem tebasan dan dampak yang ditimbulkan di Kabupaten Jember. Ada beberapa aspek yang perlu diperhatikan dalam menilai setiap faktor, yaitu (Sianipar dan Entang, 2003):

1, Urgensi faktor terhadap tujuan, terdiri dari Nilai Urgensi (NU) dan Bobot Faktor (BF). 
2. Dukungan faktor terhadap tujuan, terdiri dari Nilai Dukungan (ND) dan Nilai Bobot Dukungan (NBD).

3. Keterkaitan antar faktor terhadap tujuan, terdiri dari Nilai Keterkaitan (NK), Nilai Rata-rata Keterkaitan (NRK), dan Nilai Bobot Keterkaitan (NBK).

Penilaian NU, ND, dan NK menggunakan skala nilai antara $1-5$ dimana:

a. Angka 5 artinya, sangat tinggi nilai urgensinya.

b. Angka 4 artinya, tinggi nilai urgensinya.

c. Angka 3 artinya, cukup tinggi nilai urgensinya.

d. Angka 2 artinya, kurang nilai urgensinya.

e. Angka 1 artinya, sangat kurang nilai urgensinya.

Penilaian setiap faktor pendorong dan faktor penghambat tersebut dapat dilakukan secara kuantitatif, tetapi tanpa didukung dengan data yang akurat sangat sulit dilakukan. Faktor pendorong tersebut berasal dari strengths dan opportunities, sedangkan faktor penghambat berasal dari weaknesses dan threats. Secara umum, maka penilaian tersebut dapat dilakukan menggunakan nilai kualitatif yang dikuantifikasikan dengan menggunakan skala nilai antara $1-5$ seperti pada penjelasan di atas. Menentukan aspek Nilai Urgensi (NU) dari setiap faktor pendorong dan penghambat, maka dapat dilakukan dengan teknik komparasi. Teknik komparasi disini yaitu dengan membandingkan antara satu faktor dengan faktor lainnya.

Pada penilaian urgensi faktor ini maka didesain suatu format komparasi seperti pada Tabel 1 .

Tabel 1. Tingkat Urgensi antar Faktor Pendorong

\begin{tabular}{|c|c|c|c|c|c|c|c|}
\hline \multirow[t]{2}{*}{ No. } & \multirow[t]{2}{*}{ Faktor Pendorong } & \multicolumn{4}{|c|}{ Tingkat Komparasi Urgensi Faktor } & NU & $\mathrm{BF}$ \\
\hline & & D1 & D2 & D3 & D. & & \\
\hline D1 & & $\mathrm{x}$ & & & & & \\
\hline D2 & & & $\mathrm{X}$ & & & & \\
\hline D3 & & & & $\mathrm{X}$ & & & \\
\hline D... & & & & & $\mathrm{x}$ & & \\
\hline
\end{tabular}

Total Nilai Urgensi (TNU)....

\section{Sumber: Sianipar dan Entang, 2003}

Untuk penentuan nilai aspek urgensi (NU) pada faktor penghambat sama seperti pada penentuan NU pada faktor pendorong.
Pada penilaian urgensi faktor penghambat ini maka didesain suatu format komparasi seperti tertera pada Tabel 2. 


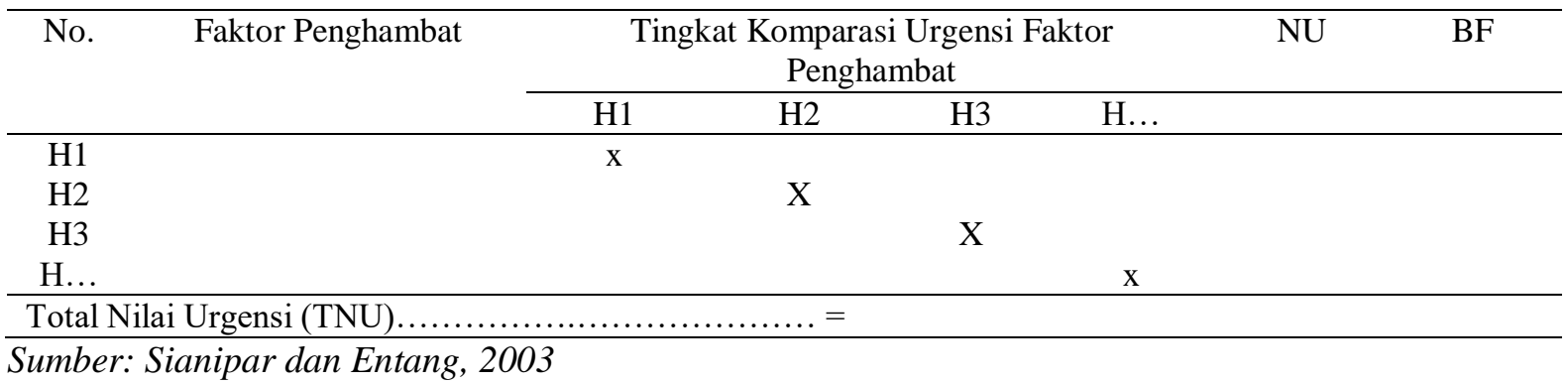

Nilai BF diperoleh dari: NU/TNU x $100 \%$ Selanjutnya NU dan BF tiap faktor pendorong dan penghambat dimasukkan Tabel 3. Evaluasi Faktor Pendorong dan Penghambat ke dalam kolom masing-masing yang telah ditentukan pada tabel 3 yakni Evaluasi Faktor Pendorong dan Penghambat.

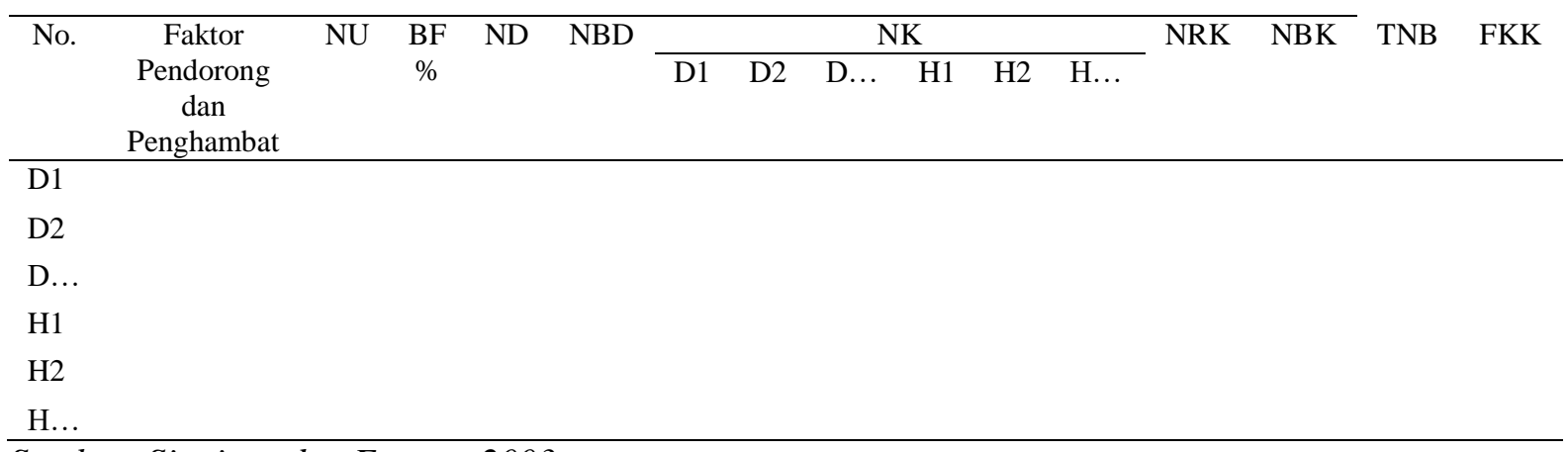

Sumber: Sianipar dan Entang, 2003

Nilai NBD diperoleh dari: ND x BF

Nilai NRK diperoleh dari: TNK/(N-1), dimana TNK yakni jumlah nilai keterkaitan satu faktor dan $\mathrm{N}$ yakni jumlah faktor pendorong dan penghambat yang dinilai.

Nilai NBK diperoleh dari: NRK x BF

Nilai TNB diperoleh dari: NBD + NBK

Untuk melakukan penilaian terhadap faktor pendorong dan penghambat maka digunakan Faktor Kunci Keberhasilan (FKK). FKK itu merupakan faktor-faktor kunci strategis. Faktor kunci keberhasilan pendorong dipilih dari kategori strengths 2 faktor, dari kategori opportunities 2 faktor, dan dari penghambat kategori weaknesses 2 faktor, dari kategori threats 2 faktor. Penentuannya dengan cara sebagai berikut (Sianipar dan Entang, 2003):
1. Pilih masing-masing faktor penghambat dan faktor pendorong berdasarkan TNB atau Nilai Total Bobot Faktor yang terbesar.

2. Jika TNB sama maka dipilih BF terbesar.

3. Jika BF sama maka dipilih Nilai Bobot Dukung atau NBD terbesar.

4. Kalau NBD sama maka dipilih Nilai Bobot Keterkaitan atau NBK terbesar.

5. Kalau NBK sama maka pilih berdasarkan pengalaman dan pertimbanagn yang rasional. 
Kalau TNB pendorong lebih besar daripada TNB penghambat berarti organisasi memiliki keunggulan meningkatkan kinerja dan bila lebih kecil sebaliknya yang terjadi.

Berdasarkan kegiatan identifikasi faktor pendorong dan penghambat, dilakukan pengambilan keputusan dalam analisis Medan Kekuatan yakni sebagai berikut (Dinas Perkebunan Propinsi Jawa Timur, 2002):

1. Mengidentifikasi solusi masalah dengan mencari aktivitas atau kegiatan yang dapat meningkatkan lebih dari satu kekuatan pendorong atau mencari aktivitas atau kegiatan yang dapat mengurangi kekuatan penghambat.

2. Mengidentifikasi aktivitas strategis yaitu mengumpulkan aktivitas-aktivitas yang berhasil diidentifikasi dari semua masalah yang dapat diperoleh solusinya.

Strategi yang tepat dalam meminimalkan dampak negatif dari adanya sistem tebasan di Kabupaten Jember dapat ditentukan dengan menganalisis faktorfaktor pendorong dan penghambat yang telah diperoleh dari hasil analisis FFA.

Tabel 4. Jumlah Penduduk Desa Curah Kalong

\begin{tabular}{lr}
\multicolumn{1}{c}{ Jenis Kelamin } & Jumlah Penduduk (Jiwa) \\
\hline Laki-laki & 7.434 \\
Perempuan & 8.030 \\
\hline Total Penduduk & 15.464 \\
\hline
\end{tabular}

Sumber: UPTD Bangsalsari, 2017

Berdasarkan Tabel 4. menunjukkan bahwa Desa Curahkalong ini memiliki potensi SDM yang tinggi. Tingkat
Menurut Sianipar dan Entang (2003), strategi yang paling efektif adalah menghilangkan atau meminimalisasi hambatan kunci dan optimalisasi atau mobilisasi pendorong kunci kearah kinerja yang akan dicapai. Pendekatan demikian merupakan strategi fokus. Artinya kekuatan kunci yang dipilih difokuskan kearah kinerja yang telah ditetapkan.

\section{HASIL DAN PEMBAHASAN}

\section{Potensi Pertanian Di Lingkungan Kelompok Tani Sumber Klopo I}

Kelompok Tani Sumber Klopo I adalah salah satu kelompok tani yang berada di wilayah Dusun Sumberklopo, Desa Curah Kalong Kecamatan Bangsalsari. Posisi desa ini berada di dataran tinggi dengan ketinggian 49 mdpl dengan luas $14,11 \mathrm{~km}^{2}$, luas desa Curahkalong $\pm 1411 \mathrm{Ha}$, jarak desa ke kantor Kecamatan Bangsalsari adalah 7 Km. Desa Curahkalong terbagi menjadi 3 Padukuhuan/ Dusun dengan 33 RW dan 85 RT. Data berikut akan menunjukkan jumlah penduduk Desa Curah Kalong. 
Volume 02, No 02- September 2018

ISSN: 2581-1339 (Print), ISSN: 2615-4862 (Online)

bahwasanya mayoritas penduduk bekerja

komposisi rumah tangga berdasarkan di sector pertanian. Tabel berikut akan sector mata pencaharian.

menunjukkan lebih rinci mengenai

Tabel 5. Jumlah Rumah Tangga Berdasarkan Sektor Mata Pencaharian

\begin{tabular}{lr}
\hline \multicolumn{1}{c}{ Sektor Mata Pencaharian } & Jumlah Rumah Tangga \\
\hline Pertanian & 1.490 \\
Industri/Kerajinan & 112 \\
Konstruksi & 14 \\
Perdagangan & 331 \\
Angkutan & 58 \\
Lainnya & 1.572 \\
\hline
\end{tabular}

Sumber: UPTD Bangsalsari, 2017

Dari data pada Tabel 5 dapat dismpulkan bahwasanya mayoritas penduduk Desa Cuarhakalong bermata pencaharian di sector pertanian dengan jumlah 1.490 rumah tangga. Pertanian di desa ini terbagi menjadi 3 kategori, yakni pertanian lahan sawah (297 ha), tegal (148,7 ha), dan pekarangan (109,2 ha). Untuk pertanian lahan sawah terdiri dari pengairan teknis (91 ha) dan semi teknis (206 ha).Potensi pertanian yang ada di Desa Curah Kalong diperkuat dengan adanya kelembagaan kelompok tani. Terhitung 6 kelompok tani yang ada dengan kondisi aktif. Lebih lengkapnya mengenai data kelompok tani ini dapat di lihat dalam tabel berikut.

Tabel 6. Data Kelompok Tani Di Desa Curah Kalong

\begin{tabular}{|c|c|c|c|c|c|c|c|c|c|}
\hline \multirow{2}{*}{$\mathrm{N}_{0}$} & \multirow{2}{*}{ Kelompok Tani } & \multicolumn{3}{|c|}{ Nama } & \multirow{2}{*}{$\begin{array}{l}\text { Jumlah } \\
\text { Anggota }\end{array}$} & \multicolumn{3}{|c|}{ Luas Lahan $(\mathrm{Ha})$} & \multirow{2}{*}{ Pola Usaha Tani } \\
\hline & & Ketua & Sekretaris & Bendahara & & Sawah & Tegal & Pekarangan & \\
\hline 1 & Krajan I & Abdul Hamid & Edi Sucipto & Burawi & 145 & 55 & 7 & 18 & Tanaman Pangan - Palawija - Perkebunan \\
\hline 2 & Krajan II & Toyo & Janu & Nito & 162 & 31 & 0 & 16 & Tanaman Pangan - Palawija - Perkebunan \\
\hline 3 & Cr kalong Tgh I & Maryono & Khotib & Novian P & 169 & 41,17 & 0 & 15 & Tanaman Pangan - Palawija - Perkebunan \\
\hline 4 & Cr kalong Tgh II & Nurhasan & Sivadi & P. Tila & 380 & 59 & 18 & 15 & Tanaman Pangan - Palawija - Perkebunan \\
\hline 5 & Sumber klopo I & Teguh Wahyudi & Husen & Mistarum & 319 & 54,12 & 53,2 & 12 & Tanaman Pangan - Palawija - Perkebunan \\
\hline 6 & Sumber klopo II & Mursid & Musleh & Anom & 219 & 38 & 37,2 & 8 & Tanaman Pangan - Palawija - Perkebunan \\
\hline
\end{tabular}

Sumber: UPTD Bangsalsari, 2017

Keterangan: Data luas lahan (ha) di atas adalah khusus untuk tanaman pangan

Dari 6 kelompok tani yang ada, dapat disimpulkan bahwasanya petani Desa Curah Kalong menerapkan sistem usahatani dengan pola tanaman panganpalawija-perkebunan. Potensi tanaman pangan yang dihasilkan yakni komoditas padi. Untuk palawija yang dihasilkan beragam yakni jagung, kedelai, dan kacang tanah. Sedangkan untuk perkebunan berupa kopi dan tebu. Potensi pertanian ini kurang didukung dengan adanya kelembagaan ekonomi pedesaan. Data dari 
UPTD Bangsalsari tahun 2017 menunjukkan bahwasanya kelembagaan ekonomi pedesaan yang ada hanya 2 unit kios sarana produksi pertanian.

Berbicara mengenai potensi pertanian yang ada di Kelompok Tani Sumber Klopo I secara garis besar telah digambarkan pada beberapa paragraph sebelumnya. Potensi pertanian di Kelompok Tani Sumber Klopo I terbilang besar. Pola usahatani yang ada yakni tanaman pangan-palawija-perkebunan. Untuk tanaman pangan yang dihasilkan berupa padi dan singkong, untuk palawija yakni jagung dan kacang tanah, sedangkan untuk perkebunan yakni kopi jenis robusta. Lahan pertanian diairi dengan sistem irigasi semi teknis.

Berbicara mengenai komoditas padi yang dihasilkan di sana tidak hanya berupa padi biasa/beras putih saja, namun kelompok tani sudah mulai berproduksi beras merah dan beras hitam. Untuk beras merah memiliki luas tanam 1,4 ha, sedangkan untuk beras hitam masih 0,25 ha. Hasil produksi beras merah ini meskipun masih dalam tahap pengembangan, namun telah memiliki pangsa pasar tersendiri baik di lingkup konsumen perorangan maupun koperasi di Kabupaten Jember. Pasar luar kabupaten juga terbuka luas, terbukti terdapat tawaran dari PT. Bumi Mas yang bersedia untuk menjalin kerjasama dengan
Kelompok Tani Sumber Klopo I ini dalam hal pemasaran beras merah, namun peluang kerjasama ini masih belum terealisasi hingga kini.

Kondisi pertanian di Sumber Klopo I ini, jika ditelisik dari gangguan atau serangan Organisme Pengganggu Tanaman (OPT) memiliki resiko yang kecil. Jarang sekali petani mengeluhkan serangan hama maupun penyakit yang sering dialami oleh petani di desa lain. Hal ini dikarenakan lokasi daerah yang merupakan dataran tinggi dan masih terjaga ekosistemnya sehingga OPT dapat ditekan. Kondisi ini berlaku untuk semua jenis pertanian yang ada disana.

Luas lahan untuk pertanian tanaman pangan di Kelompok Tani Sumber Klopo I mencapai 54,12 ha, untuk lahan tegal seluas 53,2 ha, dan untuk lahan pekarangan 12 ha. Untuk perkebunan kopi yang ada seluas 50 ha. Selain menghasilkan beberapa komoditas yang telah disebutkan, Kelompok Tani Sumber Klopo I juga memiliki potensi sebagai penghasil pisang. Tercatat seluas 15 ha lahan yang digunakan sebagai areal penanaman pisang.

Potensi lain yang dimiliki oleh Kelompok Tani Sumber Klopo I ini juga datang dari SDM anggota kelompok tani. Kelompok yang terdiri dari 75 anggota ini tergolong dalam kelompok yang aktif dan tanggap terhadap inovasi baru. 
Pelaksanaan kegiatan pertemuan rutin kelompok diadakan setiap satu bulan sekali pada hari Kamis yang juga di hadiri oleh Petugas Penyuluh Lapang. Setiap ada inovasi baru, selalu diterima dan di praktikkan dengan baik. Kondisi ini juga memperkuat perkembangan pertanian di Kelompok Tani Sumber Klopo I.

\section{Strategi Pengembangan Pertanian Kelompok Tani Sumber Klopo I}

Strategi dapat diartikan sebagai metode atau rencana atau cara yang digunakan untuk mencapai tujuan jangka panjang. Manfaat strategi adalah untuk mengoptimalkan sumber daya unggulan dalam memaksimalkan pencapaian sasaran kinerja. Dalam usahanya untuk meningkatkan pendapatn usahatani padi di Kabupaten Jember diperlukan berbagai strategi yang tepat. Strategi tersebut dapat berasal dari pemerintah ataupun dari pihak petani sendiri sebagi pelaku utama usaha.

Penentuan strategi yang tepat dapat diperoleh dari hasil analisis FFA. Menurut Sianipar dan Entang (2003), strategi yang paling efektif adalah menghilangkan atau meminimalisasi hambatan kunci dan optimalisasi, atau mobilisasi pendorong kunci kearah kinerja yang akan dicapai. Pendekatan demikian merupakan strategi fokus. Artinya kekuatan kunci yang dipilih di fokuskan kearah kinerja yang telah ditetapkan. Faktor kunci pendorong yang telah terpilih di fokuskan secara merata kearah kinerja yang akan dicapai. Demikian penghambat kunci yang terpilih perbaikannya diarahkan dalam mendukung pencapaian kinerja yang diinginkan. Dalam menyusun arah pengoptimalisasian pendorong kunci dan arah perbaikan penghambat kunci menuju kinerja yang akan dicapai agar diperhatikan kecocokannya dengan kinerja yang dicapai. Kalau tidak ada kesesuaian sebaiknya dikaji ulang ketepatan pemilihan FKK. Dengan cara demikian akan terjadi sinergi antara satu pendorong kunci dan penghambat kunci dalam mencapai kinerja.

Penyusunan strategi pada dasarnya adalah untuk menciptakan tindakan atau response terhadap perubahan eksternal yang terjadi yang dipandang dapat membawa dampak buruk terhadap organisasi seperti; perubahan teknologi, perubahan politik, ekonomi, budaya, kebijakan pemerintah. Perubahan eksternal tersebut dapat diantisipasi dengan perbaikan kondisi internal dari suatu organisasi. Nurkholis (2001) mengemukakan bahwa strategi pada hakekatnya merupakan rencana tindakan yang bersifat umum, berjangka panjang (berorientasi ke masa depan), dan cakupannya luas. Oleh karena itu, strategi biasanya dirumuskan dalam kalimat yang kandungan maknanya sangat umum dan 
tidak merujuk pada tindakan spesifik atau rinci. Namun demikian dalam perencanaan strategis tidak berarti bahwa "tindakan rinci dan spesifik" yang biasanya dirumuskan dalam suatu program kerja tidak harus disusun. Sebaliknya programprogram kerja tersebut harus direncanakan pula dalam proses perencanaan strategis dan bahkan harus dapat dirumuskan atau didefinisikan ukuran kinerjanya.

Pengembangan potensi pertanian yang ada pada Kelompok Tani Sumber Klopo I memiliki beberapa faktor pendorong dan penghambat diantaranya seperti pada Tabel 7.

Tabel 7. Faktor Pendorong dan Penghambat Pengembangan Potensi Pertanian di Kelompok Tani Sumber Klopo I

\begin{tabular}{|c|c|c|c|}
\hline No. & Faktor Pendorong & No. & Faktor Penghambat \\
\hline \multicolumn{2}{|r|}{ Strength (Kekuatan) } & \multicolumn{2}{|r|}{ Weakness (Kelemahan) } \\
\hline D1 & Lahan subur & $\mathrm{H} 1$ & Ketersediaan air irigasi yang kurang \\
\hline D2 & $\begin{array}{l}\text { Aktifnya kegiatan kelompok tani } \\
\text { (penyuluhan/pelatihan) }\end{array}$ & $\mathrm{H} 2$ & Lokasi berada di daerah pegunungan \\
\hline D3 & $\begin{array}{l}\text { Sumber daya alam melimpah (kopi, pisang, padi, } \\
\text { ketela, dan tanaman lain) }\end{array}$ & $\mathrm{H} 3$ & Kelembagaan ekonomi pedesaan masih minim \\
\hline No. & Faktor Pendorong & No. & Faktor Penghambat \\
\hline & Opportunities (Peluang) & & Threath (Ancaman) \\
\hline D4 & Kelompok tani terbuka akan inovasi baru & $\mathrm{H} 4$ & Akses sarana komunikasi masih sulit \\
\hline D5 & Kelompok tani mudah mengadopsi inovasi & H5 & $\begin{array}{l}\text { Teknologi dalam pertanian maupun olah hasil } \\
\text { masih minim }\end{array}$ \\
\hline D6 & Pasar terbuka untuk hasil produksi & & \\
\hline
\end{tabular}

Dari beberapa faktor pendorong dan penghambat yang ada tersebut dicari beberapa faktor pendorong dan penghambat sebagai kendala dan peluang dalam upaya pengembangan potensi pertanian di
Kelompok Tani Sumber Klopo I dengan menggunakan analisis FFA atau Force Field Analysis. Dari beberapa responden kunci yang telah dipilih menunjukkan hasil sebagai berikut:

Tabel 8. Indentifikasi Faktor Pendorong dan Penghambat Upaya Pengembangan Potensi Pertanian pada Kelompok Tani Sumber Klopo I

\begin{tabular}{|c|c|c|c|c|c|}
\hline No. & Faktor Pendorong & TNB & No. & Faktor Penghambat & TNB \\
\hline & Strengths & & & Weaknesses & \\
\hline D1 & Lahan subur & 0.34 & $\mathrm{H} 1$ & Ketersediaan air irigasi yang kurang & 1.02 \\
\hline D2 & $\begin{array}{l}\text { Aktifnya kegiatan kelompok tani } \\
\text { (penyuluhan/pelatihan) }\end{array}$ & 0.73 & $\mathrm{H} 2$ & Lokasi berada di daerah pegunungan & 0.42 \\
\hline \multirow[t]{3}{*}{ D3 } & $\begin{array}{l}\text { Sumber daya alam melimpah (kopi, } \\
\text { pisang, padi, ketela, dan tanaman lain) }\end{array}$ & 1.45 & $\mathrm{H} 3$ & $\begin{array}{l}\text { Kelembagaan ekonomi pedesaan masih } \\
\text { minim }\end{array}$ & $1.60^{*}$ \\
\hline & Total Strengths & 2.52 & & Total Weaknesses & 3.04 \\
\hline & Opportunities & & & Threaths & \\
\hline D4 & Kelompok tani terbuka akan inovasi baru & $1.92 *$ & $\mathrm{H} 4$ & Akses sarana komunikasi masih sulit & $2.90^{*}$ \\
\hline D5 & $\begin{array}{l}\text { Kelompok tani mudah mengadopsi } \\
\text { inovasi }\end{array}$ & 1.27 & H5 & $\begin{array}{l}\text { Teknologi dalam pertanian maupun } \\
\text { olah hasil masih minim }\end{array}$ & 1.28 \\
\hline \multirow[t]{3}{*}{ D6 } & Pasar terbuka untuk hasil produksi & $2.36^{*}$ & & & \\
\hline & Total Opportunities & 5.55 & & Total Threaths & 4.18 \\
\hline & Total Faktor Pendorong & 8.07 & & Total Faktor Penghambat & 7.22 \\
\hline
\end{tabular}

Keterangan: *) Faktor utama kendala dan peluang dalam upaya pengembangan potensi pertanian di Kelompok Tani Sumber Klopo I

Sumber: Data Primer Diolah 
Dari hasil perhitungan analisis FFA seperti pada Tabel 4.5, faktor D4 dan D6 merupakan faktor kunci pendorong/faktor peluang utama sedangkan faktor $\mathrm{H} 3$ dan H4 merupakan faktor kunci penghambat/ faktor kendala utama. Total TNB faktor pendorong lebih besar dari total TNB faktor penghambat. Nilai TNB faktor pendorong sebesar 8,07 sedangkan total TNB faktor penghambat sebesar 7,22. Nilai TNB factor pendorong jauh lebih besar dari TNB factor penghambat dengan selisih 0,85 sehingga hal ini menunjukkan bahwasanya faktor pendorong lebih dominan dan sangat mendukung dalam upaya pengembangan potensi pertanian yang ada di lingkungan Kelompok Tani Sumber Klopo I.

Kedua faktor penghambat $\mathrm{H} 3$ (kelembagaan ekonomi pedesaan masih minim) dan H4 (akses sarana komunikasi masih sulit), jika dibiarkan lebih lanjut akan dapat menghambat faktor kunci pendorong yang ada. Dengan adanya kelembagaan ekonomi pedesaan yang hanya 2 unit kios sarana produksi pertanian dan akses sarana komunikasi yang masih sulit karena signal profider yang susah diakses, maka akan dapat menghambat proses adopsi inovasi serta peluang pasar. Oleh karena itu, diperlukan beberapa strategi yang dapat menekan seminimal mungkin faktor penghambat dan memaksimalkan faktor pendorong.
Alternatif strategi yang dapat dilakukan sebagai upaya pengembangan potensi pertanian di Kelompok Tani Sumber Klopo I diantaranya:

1) Pemberdayaan kelembagaan serta organisasi petani

Kelembagaan adalah suatu jaringan yang terdiri dari sejumlah orang atau lembaga untuk tujuan tertentu, memiliki aturan dan norma, serta memiliki struktur. Dalam hal ini lembaga dapat memiliki struktur yang tegas dan formal, dan lembaga dapat menjalankan satu fungsi kelembagaan atau lebih. Menurut Basuki et al (2006), kelembagaan pertanian memiliki delapan jenis kelembagaan, yaitu 1) kelembagaan penyedia input, 2) kelembagaan penyedia modal, 3) kelembagaan penyedia tenaga kerja, 4) kelembagaan penyedia lahan dan air, 5) kelembagaan usaha tani, 6) kelembagaan pengolah hasil usaha tani, 7) kelembagaan pemasaran, 8) kelembagaan penyedia informasi.

Kelembagaan pertanian yang ada di lokasi penelitian hanya terdapat 2 unit kios sarana produksi pertanian. Kios ini menyediakan berbagai macam kebutuhan input pertanian seperti benih, pupuk, obatobatan pertanian, perlengkapan dan peralatan pertanian. Lokasi 2 unit kios ini berada jauh dari lokasi petani yang tergabung dalam kelompok tani Sumber Klopo I. Jarak antara kios dengan lokasi 
petani yakni berkisar $5 \mathrm{Km}$. Dengan kondisi ini petani merasa kesulitan dalam mengakses sarana produksi pertanian mengingat selain jaraknya yang jauh, akses menuju lokasi kios juga cukup sulit dengan petani harus "turun gunung" melalui jalan yang berbatu.

Petani serangkali mengungkapkan bahwasanya untuk lokasi dataran tinggi seperti lokasi Kelompok Tani Sumber Klopo I ini, sangat diperlukan ketersediaan kelembagaan pertanian yang mudah untuk diakses. Hal ini dimaksudkan untuk mempermudah penyediaan sarana produksi dan mengurangi biaya angkut dalam pembelian sarana produksi. Petani menginginkan adanya kios pertanian di lokasi Desa Sumber Klopo, namun hal ini masih sangat sulit untuk diupayakan.

Salah satu upaya yang bisa dilakukan yakni dengan memaksimalkan peran kelembagaan kelompok tani yang ada di Desa Sumber Klopo sendiri serta pengoptimalan organisasi petani di dalamnya. Menurut Departemen Pertanian (2007), pengembangan kelompok tani diarahkan pada peningkatan kemampuan kelompok tani dalam melaksanakan fungsinya, peningkatan kemampuan para anggota dalam pengembangan agribisnis, penguatan kelompok tani menjadi organisasi petani yang kuat dan mandiri. Potensi kelompok tani sangat besar dalam mendukung dan melaksanakan berbagai program pembangunan pertanian. Program pemberdayaan kelompok tani harus dapat meningkatkan kemampuan kelompok tani dalam hal: (1) memahami potensi dan kelemahan kelompok, memperhitungkan peluang dan tantangan yang dihadapi pada saat mendatang, (3) memilih berbagai alternatif yang ada untuk mengatasi masalah yang dihadapi, (4) menyelenggarakan kehidupan berkelompok dan bermasyarakat yang serasi dengan lingkungannya secara berkesinambungan (Hermanto dan Swastika, 2011).

Pendekatan penguatan dan pelibatan masyarakat desa dalam pemberdayaan kelembagaan adalah memberi ruang penuh mengartikulasikan diri mereka dan lingkungannya, sesuai realitas sosial masyarakat perdesaan. Lembaga yang sekarang berkembang di perdesaaan merupakan lembaga modern, karena umumnya telah memiliki: (1) struktur dan tata nilai yang yang jelas, (2) telah diformalkan dengan terdapatnya kepastian anggota dan proses pelaksanaan, (3) adanya aturan tertulis dalam anggaran dasar dan rumah tangga, (4) adanya kepemimpinan yang resmi, dan (5) biasanya sengaja dibentuk karena tumbuhnya kesadaran pentingnya keberadaan lembaga tersebut (Elizabeth, 2007 dalam Subekti et al, 2015). 
Peningkatan kapasitas

kelembagaan petani dilakukan sejalan dengan kegiatan penyuluhan pertanian dengan memotivasi petani untuk berpartisipasi dalam kelembagaan petani. Penyuluhan pertanian perlu dirancang dengan memberikan muatan (content area) pada penguatan kapasitas individu petani sekaligus penguatan kapasitas kelembagaan petani. Misalnya dengan membangun organisasi petani dengan unit2 pendukung system agribisnis dari penyedia sarana produksi hingga pemasaran. Hal riil yang bisa dilakukan yakni dengan membangun kelompok penyedia pupuk dan obat-obatan pertanian berbasis organic yang dihasilkan dari bahan-bahan yang tersedia di Desa Sumber Klopo, pemuliaan benih tanaman, serta pendukung pemasaran hasil pertanian.

Intervensi pemerintah dalam pengembangan kelembagaan petani ke depan tidak dapat dihindari. Penguatan kelembagaan pertanian ini membutuhkan dukungan kebijakan yang lebih fleksibel. Bentuk intervensi pemerintah disini seyogyanya lebih bersifat memfasilitasi sehingga mampu merangsang pertumbuhan kelembagaan yang bersifat terpadu.

2) Revitalisasi sistem inovasi teknologi dengan mempertimbangkan aspek penelitian, pengembangan dan jaringan inovasi interaktif
Inovasi yang diterima dan diserap oleh Kelompok Tani Sumber Klopo I diterima dari proses penyuluhan yang diberikan oleh PPL yang bertugas dan diadakan setiap 2 (dua) minggu sekali pada hari Kamis siang. Kegiatan penyuluhan ini diikuti oleh anggota kelompok yang telah memiliki ruangan pertemuan kelompok sendiri sehingga proses penyuluhan tidak dilakukan dengan system anjang sana di setiap rumah anggota kelompok yang biasanya dilakukan pada kelompok tani lain.

Kegiatan penyuluhan ini juga selalu dihadiri oleh PPL dengan inovasi penyuluhan yang variatif dari metode pemupukan, cara pembuatan pupuk organik, penanggulangan penyakit, sosialisasi kebijakan pertanian, hingga penguatan kelompok tani. Inovasi penyuluhan ini tidak hanya berasal dari instansi/pemerintah saja seperti sosialisasi kebijakan pertanian, namun juga dari kebutuhan petani.

Penyuluhan yang dilakukan ini hendaknya ditingkatkan dengan inovasi teknologi baru dengan mempertimbangkan aspek penelitian, pengembangan, dan jaringan inovasi interaktif. Artinya, penyuluhan yang merupakan kegiatan adopsi inovasi ini perlu untuk ditingkatkan dengan memberikan inovasi baru dari ilmu pengetahun yang semakin berkembang melalui hasil-hasil penelitian di bidang 
pertanian. Hasil penelitian yang dapat diakses oleh petani maupun PPL sendiri melalui media-media yang ada seperti radio, internet (jurnal penelitian maupun youtube), seminar dan pelatihan. Upaya ini tidak dapat dipisahkan dari berbagai pihak, misalnya instansi/dinas pertanian setempat, pihak perguruan tinggi, petani, dan stakeholder pertanian. Dengan metode penyuluhan seperti ini diaharapkan agar inovasi yang diterima petani semakin berkembang sehingga upaya pertanian yang dilakukan mampu untuk mencapi system agribisnis dari hulu hingga ke hilir.

3) Pengembangan akses jaringan komunikasi

Di era sekarang ini perkembangan ilmu teknologi sudah semakin canggih dan terus berkembang. Informasi yang tiap waktu terus terbarukan menjadi salah satu kebutuhan bagi manusia yang saat ini dikenal dengan era milenial. Akses terhadap segala bentuk informasi saat ini tidak hanya bersumber dari media televisi, radio, ataupun media cetak namun sekarang telah berkembang media komunikasi melalui smart phone dengan akses internet yang bisa diakses dimanapun dan kapanpun.

Jaringan komunikasi dewasa ini menjadi hal yang dibutuhkan, tidak hanya komunikasi secara langsung, namun komunikasi secara tidak langsung pun demikian. Jaringan komunikasi yang baik akan memberikan berbagai dampak positif bagi penggunanya. Perkembangan informasi dan komunikasi khususnya melalui media digital seperti saat ini menjadi tidak terbendung. Dengan kata lain arus informasi dan komunikasi saat ini selalu mengalami pembaharuan dan kemajuan tiap harinya dari berbagai bidang keilmuan tidak terkecuali pertanian, sehingga petani dan para pelaku pertanian saat ini dapat mengetahui dan mengakses informasi dengan cepat.

Petani di Desa Sumber Klopo secara umum masih belum bisa menikmati jaringan informasi dan komunikasi secara lancer. Hal ini dikarenakan lokasi desa yang berada pada daerah dataran tinggi serta tidak terjangkaunya signal komunikasi dari berbagai provider. Kondisi ini mengakibatkan petani Desa Sumber Klopo sulit untuk berkomunikasi dengan pihak lain melalui seluler, serta sulit untuk mengakses informasi melalui media internet. Kelemahan akses komunikasi ini perlu untuk diperbaiki dengan menjalin pihak pemerintah dan provider tertentu untuk bisa bekerjasama memajukan Desa Sumber Klopo.

\section{KESIMPULAN}

Beberapa simpulan yang dapat diperoleh dari hasil penelitian ini diantaranya: 
1. Potensi pertanian yang dimiliki Kelompok Tani Sumber Klopo I yakni:

a) kelompok ini memiliki SDM yang aktif dalam kegiatan kelompok tani dan aktif dalam adopsi inovasi,

b) memiliki potensi penghasil panganpalawija-perkebunan dengan komoditas pangan utama yang dihasilkan yakni padi sedangkan perkebunan yakni kopi,

c) memiliki potensi lahan pertanian yang subur,

d) memiliki 2 unit kios sarana produksi pertanian, dan

e) memiliki resiko gangguan OPT yang kecil.

\section{DAFTAR PUSTAKA}

Departemen Pertanian. 2007. Pedoman Pertumbuhan Dan Pengembangan Kelompok Tani Dan Gabungan Kelompok Tani. Jakarta.

Hermanto dan Swatika. 2011. Penguatan Kelompok Tani: Langkah Awal Peningkatan Kesejahteraan Petani. Bogor: Pusat Sosial Ekonomi dan Kebijakan Pertanian.

Sianipar dan Entang. 2003. Teknik-Teknik Analisis Maanajemen. Jakarta: Lembaga Administrasi Negara.

Soetriono dan Rita Hanafie. 2007. Filsafat Ilmu dan Metodologi Penelitian. Yogyakarta: CV. Andi Offset.

Subekti, S. et al. 2015. Penguatan Kelompok Tani Melalui Optimalisasi Dan Sinergi Lingkungan Sosial. [jurnal on line] JSEP Vol. 8 No.3
2. Beberapa bentuk strategi pengembangan pertanian yang dapat diterapkan yakni: a) Pemberdayaan kelembagaan serta organisasi petani

b) Revitalisasi sistem inovasi teknologi dengan mempertimbangkan aspek penelitian, pengembangan dan jaringan inovasi interaktif

c) Pengembangan akses jaringan komunikasi.

\section{UCAPAN TERIMA KASIH}

Penulis mengucapkan terima kasih kepada Universitas Muhammadiyah Jember, petani Desa Sumber Klopo, serta Yudi Cristian selaku PPL yang telah memberikan bimbingan, pengarahan, saran dan masukan yang sangat berharga dan bermanfaat bagi penulis dalam penyusunan jurnal ini. November 2015. Diakses pada tanggal 23 Desember 2017. 